\title{
BIOLOGICAL CONTROL OF FOOT ROT DISEASE OF RICE USING FERMENTED PRODUCTS OF COMPOST AND VERMICOMPOST
}

\author{
T. Manandhar* and K. D. Yami* \\ *Nepal Academy of Science and Technology, Khumaltar, Nepal.
}

\begin{abstract}
Field trial experiment was conducted at the premise of Nepal Academy of Science and Technology during rainy season (April-June) in 2004 under the rainfed condition. In this study, four types of compost tea: aerated vermicompost tea (ACTV), non aerated vermicompost tea (NCTV), aerated compost tea (ACTC) and non aerated compost tea (NCTV) was prepared and investigated for the suppression of Foot rot disease of Rice caused by Fusarium moniliforme Sheldon Gibberella fujikuroi. The result was compared with carbendazium (2.5 g per kg dry seeds) treatment and water check. And data was analyzed using one way ANOVA. Among these four compost tea, ACTV showed statistically significant maximum control (25.6\% increment of healthy seedlings), followed by ACTC (22.4\% increment of healthy seedlings). Least effect was obtained by NCTC (13.6\% increment of healthy seedlings). It was observed that $18 \%$ of collected Khumal-4 variety rice was infected with Fusarium monoliforme as revealed by Standard Moist Blotter Technique. In concurrence with field trial experiment, treatment of the rice seeds in the Standard Blotter Technique with compost tea revealed highest efficiency of ACTV in reducing the number of affected seeds ( $12 \%$ reduction in affected seeds) followed by ACTC (10\% reduction) and NCTV ( $8 \%$ reduction). NCTC were found to be least effective (6\% reduction) among the four types of compost tea. Application of compost tea also increases the percentage of germination of seeds, with maximum effect obtained by ACTV (98\%).
\end{abstract}

Keywords: Compost tea; Vermicompost tea; Foot rot; Fusarium moniliforme.

\section{INTRODUCTION}

One of the major challenges facing organic producers today is disease management. Cultural methods of disease control are commonly used on organic farms. The application of organic chemicals for disease control is often a last resort and regulated while biological control is still not readily available. The use of compost extracts, then, presents a simple, inexpensive and potentially effective method to supplement the on-farm disease management program.

"Bakanae" caused by Fusarium moniliforme Sheldon Gibberella fujikuroi is a disease of rice first described in Japan, and now widely distributed in Asia and if no control measures are taken, it may be a factor limiting rice production (Johnston, 1967). The typical symptom is the abnormal elongation of seedlings. The pathogen has a wide host range and is widespread throughout the world. On rice, F. moniliforme induces seedling elongation, foot rot, seedling rot, grain sterility, and grain discoloration (Ou, 1985). The pathogen can be both seed-borne and soil borne. Generally, the seed-borne inoculum provides initial foci for secondary infection. Under favorable environmental conditions, infected plants in different foci have the capacity to produce numerous conidia that subsequently infect proximate healthy plants, which results in yield loss. Significant prevalence of Bakanae Disease (gibberlin producing Gibberella fujikuroi) was reported by Desjardins et al. (2000) in Khumal-4 variety rice seeds collected from foothill regions of central Nepal (Lamjung district) and in the Kathmandu valley and adjoining regions of eastcentral Nepal (Bhaktapur, Dolakha, Kathmandu, Kavre, and Lalitpur districts).
The fungus not only causes considerable damage on many plants, but also is parasitic on plants without producing visible symptoms. Currently, the most common management practice for Bakanae is seed treatment with fungicides; however, resistance of the fungal pathogen to the fungicides has been reported (Ogawa, 1988). The persistent, injudicious use of chemicals has toxic effects on non-target organisms and can cause undesirable changes in the environment. Most of these chemicals are too expensive for the resource poor farmers of Asia, where $90 \%$ of the world's rice is grown. Large-scale and long-term use of resistant cultivars is likely to result in significant shifts in the virulence characteristics of pathogens, culminating in resistance breakdown.

Biocontrol assumes special significance being an eco-friendly and cost effective strategy which can be used in integration with other strategies for a greater level of protection with sustained rice yields. The widely quoted and accepted definition of biological control of disease is: "the reduction in the amount of inoculum or disease-producing activity of a pathogen accomplished by or through one or more organisms."

Extracts from composted organic matter, known as compost tea, have been used for centuries for their beneficial effects on plant health (Abbasi et al., 2002). Compost tea is being used increasingly in agricultural production to control plant diseases. However, there has been limited investigation relating disease control efficacy to various compost tea production methods, particularly compost tea and vermicompost tea produced with active aeration to increase microbial population densities in compost tea. A primary reason for producing compost tea is to transfer microbial biomass, fine particulate

Author for Correspondence: T. Manandhar, Nepal Academy of Science and Technology, Khumaltar, Nepal. 
organic matter, and soluble chemical components of compost into an aqueous phase that can be applied to plant surfaces and soils in ways not possible or economically feasible with solid compost. Compost tea is being increasingly used as an alternative plant disease control measure in organic agriculture (Anonymous, 2004). The microflora of both aerated and nonaerated compost tea are typically described as being dominated by bacteria and therefore the bacterial population of the compost tea could be a useful parameter to measure in relation to plant disease suppression. It has been proposed that increasing the population of total and active bacteria in aerated compost tea will generally increase the plant disease suppression (Ingham, 2002). Various researchers have found compost tea useful for suppression of various pathogens: Apple Scab caused by Venturia inaequalis (Cronin et al., 1996), Blight on tomato and potato caused by Phytophthora infestans (Weltzien and Ketterer, 1986b), Downy Mildew on grapevine caused by Plasmopara viticola (Weltzien and Ketterer, 1986a), Grey Mold (Botrytis cinerea) on grapevine, beans, strawberry etc (Ketterer et al., 1992; Urban and Tranker, 1993; Elad and Shteinberg, 1994).

Multiple modes of action have been postulated to be involved in suppressing plant disease with compost teas. Hoitink (1990) attributed disease control by compost tea to four possible mechanisms: 1) competition for nutrients by beneficial microorganisms; 2) antibiotic production by beneficial microorganisms; 3) predation against pathogens by beneficial microorganisms; or 4) activation of disease-resistant genes in plants by compost extracts.

The results of studies on compost extracts have been variable and seem to be crop and region specific, amongst other factors. The effects of compost extract application is not consistent across all crops Therefore, a study was undertaken to look at the effectiveness of foot rot disease control with compost extracts on Khumal 4 variety rice of Kathmandu at Nepal Academy of Science and Technology.

\section{OBJECTIVES}

\subsection{General objective}

The general objective of this study was to determine the effectiveness of compost tea and vermicompost tea for the control of Foot Rot disease of rice.

\subsection{Specific objectives}

1. To study effects of compost teas on germination and mycoflora of rice seeds

2. To study the disease controlling capacity of compost teas in relation to Foot Rot disease of rice through field trial

\section{MATERIALS AND METHODS}

\subsection{Collection of Rice Seed Samples}

Rice seed sample (variety 'Khumal 4') was collected from Bastola Nagar, Nagarkot, Bhaktapur.

\subsection{Preparation of Compost Teas}

Vermicompost for the preparation of vermicompost tea was prepared using Eisenia foetida red earthworms and fruit/vegetable wastes as substrates at Nepal Academy of Science and Technology. Compost for the preparation of compost tea was prepared by conventional method and obtained from local farmers.

Non-aerated/Passive compost teas (modified from Brinton, 1995)

For the preparation of Non-aerated/ Passive compost tea, one part compost or vermicompost was mixed with 6 parts distilled water (volume per volume). The mixtures were stirred for about 10 minutes everyday for 7-10 days. Then, the extracts were filtered through four layers of muslin cloth.

Aerated compost teas (modified from Ingham, 2005)

For the preparation of Aerated compost tea, one part compost or vermicompost was mixed with 6 parts water. Air was bubbled through the mixtures using aquarium pumps for three days. The mixtures were stirred every day for a brief period. After three days, the mixtures were filtered through four layers of cheesecloth to remove solid particles.

\subsection{Study of Effects of Compost Teas on Seed Germination and Diseases Incidence by Field Trial}

The field trial was carried out in the premises of Nepal Academy of Science and Technology (NAST), Khumaltar. The trial was initiated on April 21, 2006.

For the field trial, plots $1 \times 1$ sq. $\mathrm{m}$ were prepared. Five plots were prepared for each treatment. Six treatments were maintained for the study: aerated vermicompost tea, non-aerated vermicompost tea, aerated compost tea, non-aerated compost tea, fungicide (carbendazim) and water check.

Each plot that was to be sown with compost/vermicomposttea-treated seeds was first watered (drenched) with 1 litre of respective compost tea. Similarly, each plot to be sown with fungicide treated and water check seeds were watered with 1 litre sterilized water. All the plots were left covered with plastic sheets for 24 hours.

Rice seeds were pregerminated in compost/vermicompost tea before planting. The seeds were first soaked in compost/ vermicompost teas for 24 hrs and left covered with muslin cloth in separate trays for 24 hours. The water check seeds were similarly pregerminated in water. In case of fungicidal treated seeds, the seeds were first treated with carbendazim at the rate of $2.5 \mathrm{~g}$ per kg by dry seed treatment method and left for 24 hrs before soaking them in water for pregermination.

The seeds were planted at the rate of 100 seeds per $1 \times 1$ sq. $\mathrm{m}$ plot in $10 \times 10$ array, the seeds being spaced $10 \mathrm{~cm}$. The plots were left covered with plastic sheets until the seed started germinating.

One litre vermicompost/compost tea was added, by soil drenching method, in each plot at seven-day interval. Simi- 
larly, water was added in case of fungicidal control and check treatments.

The germinated seedlings were examined for disease symptoms of foot rot disease. The observations were taken every seven days for 45 days.

\subsection{Assessment of Fusarium moniliforme and Germination by Standard Moist Blotter Method}

Standard Moist blotter method (ISTA, 2004) was used to analyze the mycoflora of rice seeds. Moist chambers were prepared by placing three layers of sterilized blotting papers moistened with sterilized water on the bottom of petridishes. The seeds were placed on the blotting paper, 25 seeds per plate, on four plates. The plates were incubated at $25 \pm 2^{\circ} \mathrm{C}$ for seven days. Fusarium moniliforme growing on the seeds were examined and identified. The number of seeds showing fungal growth was noted.

\subsection{Assessment of Effect of Compost and Vermicompost Tea on Fusarium moniliforme and Germination by Standard Moist Blotter Method}

The seeds were soaked in compost and vermicompost teas for five minutes. Seeds for carbendazim treatment were treated with carbendazim at the rate of $2.5 \mathrm{~g} \mathrm{~kg}^{-1}$ through dry seed treatment method. The water check seeds were soaked in water. Incidence of Fusarium moniliforme associated with the seeds was followed by the standard moist blotter method (ISTA 2004). Twenty-five seeds per plate were placed in a Petri plate of $9 \mathrm{~cm}$ diameter containing three well moistened blotters (Whatman No. 1). For each seed sample, one hundred seeds were used (Four replications per treatment). These plates were then incubated at $25 \pm 2^{\circ} \mathrm{C}$ under alternating cycle of $12 \mathrm{~h}$ of darkness and $12 \mathrm{~h}$ light under Near Ultra Violet (NUV) for seven days. After 7 days' incubation, the seeds were examined under stereo binocular microscope for the presence of associated seedborne fungi. If needed, the fungus species were confirmed with the aid of compound microscope and the pertinent literature. Total number of seeds infected by F. moniliforme was scored to determine percentage of seed infection.

\subsection{Isolation and Identification of Fusarium Spp. from Dis- eased Seedlings}

For the isolation from the rice seedlings showing the symptoms of foot rot, the affected seedlings were cut into $1 \mathrm{~cm}$ long pieces. The pieces were washed well in sterilized water.
The pieces were disinfected in $0.001 \%$ mercuric chloride solution for 1 minute then rinsed thoroughly in 70\% alcohol and further rinsed in three changes of sterilized water. The pieces were then blotted with sterilized blotting paper to remove excess water. The ends of the pieces were cut off with a sterilized scalpel and central parts were plated out on potato dextrose agar (PDA) plates.

\subsection{Data Analysis}

Results of field trial were analysed using one way ANOVA using SPSS/PC IBM-4 software program.

\section{RESULTS AND DISCUSSION}

\subsection{Fusarium moniliforme and Germination of the collected seeds}

The mycoflora present on the seed samples were studied through Standard Blotter Technique.

Table 1: Fusarium moniliforme and germination of rice seed sample

\begin{tabular}{|l|c|}
\hline Species / Germination & Percentage of seeds \\
\hline Fusarium moniliforme & 18 \\
\hline Germination & 88 \\
\hline
\end{tabular}

In the Standard Blotter Test, treatments with compost teas increased germination of the rice seeds (by an average of $5.5 \%)$. Compost teas also decreased the percentage of $F$. moniliforme infected seeds, but they did not completely eradicate the fungus from the seeds. However, treatment with Carbendazim, not only increased germination but also completely eradicated all mycoflora on the seeds. Maximum increment in germination (10\%) was observed in aerated compost tea of vermicompost (ACTV) followed by aerated compost tea of compost (ACTC) (table 2).

\subsection{Field Trial}

\section{Symptoms shown by the diseased seedlings}

During the field trial, the affected seedlings showed typical symptoms of Foot Rot. The affected seedlings were distinctly taller than the healthy seedlings. When uprooted, the roots broke up easily and pinkish-brown discoloration was observed at the collar region. The affected seedlings soon wilted and died. F. moniliforme, the causal agent of Foot Rot Disease, was isolated from the affected seedlings.

Table 2: Effect of treatments on germination and percentage of seeds showing growth of F. moniliforme in moist blotter technique

\begin{tabular}{|l|c|c|c|}
\hline Treatments & $\begin{array}{c}\text { Percentage of seeds showing growth of } \\
\text { Fusarium moniliforme }\end{array}$ & Germination \% & $\begin{array}{c}\text { Decrease in \% of affected seeds } \\
\text { in comparison to control }\end{array}$ \\
\hline Control & 18 & 88 & -- \\
\hline NCTV & 10 & 92 & 8 \\
\hline ACTV & 6 & 98 & 12 \\
\hline NCTC & 12 & 89 & 6 \\
\hline ACTC & 8 & 95 & 10 \\
\hline Carbendazim & 0 & 95 & 18 \\
\hline
\end{tabular}




\section{Effects of compost teas on seed germination and disease inci-} dence by field trial

The field trial experiment showed that among the compost teas, maximum effect was attained with ACTV (25.6\% increment in healthy rice seedlings) followed by ACTC (22.4\%) and NCTV (19.6\%). Least increment in the percentage of healthy seedlings was observed in case of NCTV (13.6\%). In case of Carbendazim treated seeds, 90\% germinated seedlings were healthy. The results of field trial are expressed in Table below:

Table 3: Percentage of healthy seedlings in each treatment at the end of the field trial experiment

\begin{tabular}{|c|c|c|}
\hline Treatments & $\begin{array}{c}\text { Average Number } \\
\text { of healthy } \\
\text { seedlings }\end{array}$ & $\begin{array}{c}\text { Increment in } \\
\text { comparison to } \\
\text { control }\end{array}$ \\
\hline NCTV & 74.6 & 19.6 \\
\hline ACTV & 80.6 & 25.6 \\
\hline NCTC & 68.6 & 13.6 \\
\hline ACTC & 77.4 & 22.4 \\
\hline Carbendazim & 90.0 & 35.0 \\
\hline Water check & 55 & -- \\
\hline
\end{tabular}

NCTV: Nonaerated Vermicompost Tea; ACTV: Aerated Vermicompost Tea; NCTC: Nonaerated Compost Tea; ACTC: Aerated Compost Tea

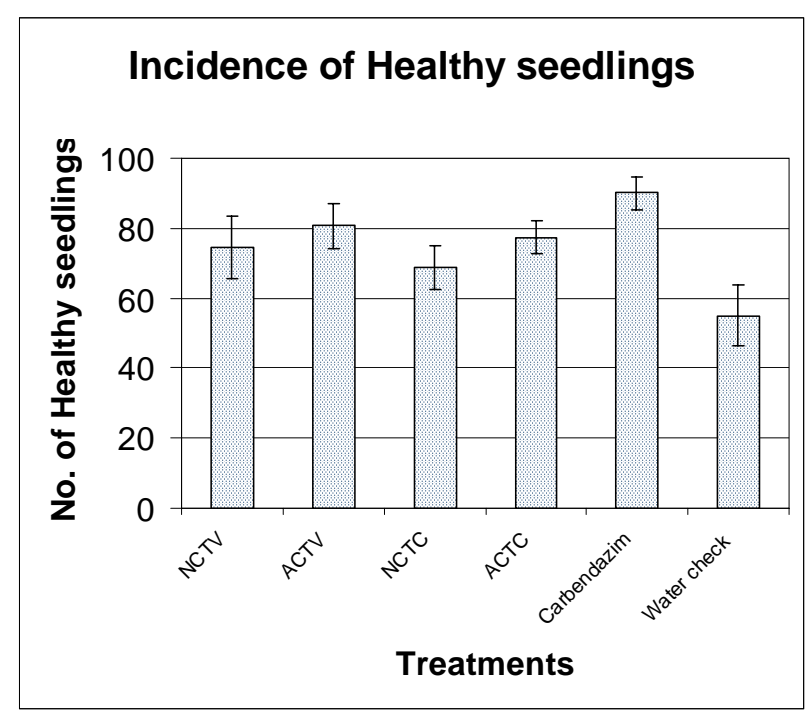

Figure 1: Chart showing incidence of healthy seedlings in various treatments

\section{DISCUSSION}

The effectiveness of using composts for disease control, particularly against fungal pathogens, has been studied extensively (Weltzein, 1991). Composts of various kinds have been used to reduce the incidence of Pythium and Rhizoctonia in a variety of vegetables and fruits (Gottschall et al., 1987; Weltzien and Ketterer, 1986). These results have led to further work using filtered extracts of composts. In some cases, the compost extracts were even more effective in controlling disease than conventional pesticides. Stindt and Weltzien (1988) at the University of Bonn achieved effective control of Botrytis cinerea in strawberries as well as blight in potatoes. Similarly, powdery mildew and root rot were significantly reduced in peas and beets in other trials in Germany (Thom and Moller, 1988).

The aim of the brewing process is to extract beneficial microbes from the compost itself, followed by growing these populations of microbes during the brew period. Compost tea can be used to fertilize crops via soil drenches or foliar applications; to inoculate crop residue to facilitate decomposition; to improve nutrient cycling in soil through increased microorganism activity and to manage certain plant pathogens through microbial competition and improved plant nutrition. However, there are multiple mechanisms that may explain the variations in disease suppression that have been observed, including different forms of competition, such as resource competition, antibiotic production, parasitism, and systemic acquired resistance.

On the basis of this study, it could be observed that the incidence of foot rot disease of rice was significantly reduced with the application of compost tea. And among the four types of compost teas tested, aerated vermicompost tea (ACTV) was found to be most effective for the management of foot rot disease.

The field trial and moist blotter experiments revealed effectiveness of aerated compost tea in the management of foot rot disease over the nonareated compost tea. There appears to be controversy about how the extracts are to be prepared, anaerobically or aerobically. Cronin and coworkers (1996), for instance, found that anaerobically prepared extracts from spent mushroom substrate were much more effective in inhibiting apple scab than aerobically treated extracts. Weltzien (1991) and Brinton (1995) also promote the anaerobic method of compost extract preparation. These researchers suggest that the likely disease-suppressive effect is a result of a metabolite produced by anaerobic microorganisms in the extract (Cronin et al., 1996). In contrast, there is also evidence that indicates that aerobically produced compost extracts are much more effective (reviewed in Anonymous, 1996). Microbiological studies have also shown that aerobic microbes dominate compost extracts (Sackenheim, 1993, Hoitink et al., 1997). Edwards et. al. (2006) in their preliminary research, have demonstrated clearly that teas produced with aeration are much

Table 4: Statistical analysis through ANOVA test (number of healthy seedlings in the field trial with respect to various treatments)

\begin{tabular}{|l|c|c|c|c|c|c|}
\hline Square of variance & d.f. & Sum of squares & Mean sum of squares & F-ratio & F at 1\% & F at 5\% \\
\hline Between classes & 5.00 & 3510.40 & 822.93 & \multirow{2}{*}{27.32} & \multirow{2}{*}{3.90} & \multirow{2}{*}{2.60} \\
\cline { 1 - 4 } Within classes & 24.00 & 1112.80 & 30.12 & & & \\
\hline Total & 29.00 & 4623.20 & & & & \\
\hline
\end{tabular}

The computed F-ratio is greater than the tabulated F-ratio at both $1 \%$ and $5 \%$ level of significance. Thus the difference between the classes is significant at both $1 \%$ and $5 \%$ 
more stable and effective than those produced without aeration. The research team identified microorganisms and plant growth regulators such as hormones, humic acids and fulvic acids (present in the vermicompost tea) as the most probable mechanisms for growth increases in tomatoes.

Most published research on the use of compost tea for disease suppression utilizes passive compost teas. Although passive compost tea is not aerated, it is not necessarily anaerobic unless additional technology and nutrients are added. If a passive tea turns anaerobic, it can putrify, rather than ferment, which may produce phenols and alcohol that can harm plants and beneficial soil microorganisms.

The vermicompost acts like a buffer for plants where soil $\mathrm{pH}$ levels are too high or low making soil nutrients available again to the plant. Vermicompost is biologically active and the castings are much higher in bacteria, organic material and available nitrogen, calcium, magnesium, phosphorus and potassium than soil itself. Yami and Shrestha (2005) assessed greater diversity of beneficial microorganisms including nitrogen fixing bacteria in the vermicompost than in the compost. Worms play a vital role in creating the optimum conditions for the beneficial organisms to establish and reproduce. These 'good' organisms compete with and dominate the more harmful microbes. There is an abundance of oxygen and nitrogenous compounds (urea, proteins and NH3) in the excreta (vermicast) and mucus secreted from the external tissues of the worms.

\section{CONCLUSION}

On the basis of this study, it could be concluded that although compost teas could not completely eradicate Fusarium moniliforme, the causal agent of foot rot disease of rice, they could bring its population to acceptable limit. The effectiveness of compost extracts appears to depend on many factors including method of preparation, extraction time, compost used and crop applied on. Consistency and maturity of the compost to be extracted are yet more variables. Evaluation is necessary on specific crops and specific disease organisms over a period of several years to account for year to year variations in weather which can significantly influence disease dynamics.

\section{ACKNOWLEDGEMENTS}

We would like to extend our sincere thanks to Nepal Academy of Science and Technology for providing the research facilities. The authors are also thankful to Mr. Shankar Raj Panta and Mr. Pramesh B. Lakhey for their help.

\section{REFERENCES}

Abbasi, P.A., Al-Dahmani, J., Sahin, F., Hoitink, H.A.J. and Miller, S.A. 2002. Effect of compost on disease severity and yield of tomato in conventional and organic production systems. Plant Disinfection. 86: $156-161$.

Anonymous. 1996. Compost teas in agriculture. BioCycle. December 1996.

Anonymous. 2004. Compost tea task force Report. April 6, 2004.
Published online by the Agricultural Marketing Service/USDA. w w w. a m s. us d a.gov/nos b/m e e t i n g / CompostTeaTakForceFinalReport.

Brinton, W.F. 1995. The control of plant pathogenic fungi by use of compost teas. Biodynamics. 197: 12-15.

Brinton, W.F., Trankner, A. and Droffner, M. 1996. Investigations into liquid compost extracts. Biocycle. Nov. 1996.

Cronin, M.J., Yohalem, D.S., Harris, R.F. and Andrews, J.H. 1996. Putative mechanism and dynamics of inhibition of the apple scab pathogen Venturia inaequalis by compost extracts. Soil Biology and Biochemistry. 28(9): 1241-1249.

Desjardins, A. E., Manandhar, H. K., Plattner, R. D., Manandhar, G. G., Poling, S. M., and Maragos, C. M. 2000. Fusarium Species from Nepalese Rice and Production of Mycotoxins and Gibberellic Acid by Selected Species. Applied and Environmental Microbiology; 66: $1020-1025$.

Edwards, C.A., Arancon, N.Q. and Greytak, S. 2006. Effects of Vermicompost Teas on Plant Growth and Plant Diseases. The Ohio State University Biocycle. May 2006 (www.jgpress.com):

Elad, Y. and Shteinberg, D. 1994. Effect of compost water extracts on grey mould (Botrytis cinerea). Crop Protection. 13(2): 109-114.

Gottschall, R.C. et al. 1987. Verwertung von Kompost aus Bioabfall: Aufbereitung von Frisch und Fertigkomposten. In: Fricke, K et al (eds.), Zwischenbericht Forschungsprojeckt: Grune biotonne Witzenhausen.

Hoitink, H.A.J, Stone, A.G. and Han, D.Y. 1997. Suppression of plant diseases by composts. HortScience. 32(2): 184-187.

Hoitink, H.A.J. 1990. Production of disease suppressive compost and container media, and microorganism culture for use therein. Patent 4960348. Feb. 13, 1990.

Ingham, E.R. 2002.The compost tea brewing manual, 3rd edn. Soil Foodweb Incorporated, Corvallis, Oregon, USA.

International Seed Testing Association (ISTA). 2004. International Rules for Seed Testing. Seed Science and Technology. 335.

Johnston, A. 1967. Chemicals for the control of rice diseases. Ciba Agro. Che., Basel. Switzerland: 20-26.

Ketterer, N., Fisher, B. and Weltzien, H. 1992. Biological control of Botrytis cinerea on grape vine by compost extracts and their microorganisms in pure culture. In: Verhoeff, K., N. Malathrakis and B. Williamson (Eds.), Recent advances in Botrytis Research, Proceedings IO’ International Botrytis Symposium, Heraklion, Crete, Greece, April 5-1, pp. 179-186.

National Organic Standards Board. 2004. Compost Tea Task Force Report, April 6, 2004. Published online by the Agricultural Marketing Service/USDA at www.ams.usda.gov/nosb/meetings/ CompostTeaTaskForceFinalReport.pdf.

Ogawa, K. 1988. Damage by "bakanae” disease and its chemical control. Jpn. Pestic. Inf. 52:13-15.

Ou, S. H. 1985. Rice diseases. 2nd edition. Commonwealth Mycol. Inst.,Kew England. 
Sackenheim, R. 1993. Untersuchungen Uber Wirkungen von Wasserigen, mikrobiologisch aktiven Extracten aus kompostierten Substraten auf den Befall der Weinrebe (Vitis diacetate in an avocado plantation mulch suppressive tovinifera) mit Plasmopora viticola, Uncinula necator, Botrytis cenerea und Pseudopezicula tracheiphila. Ph.D. thesis..Rheinische Friedrich-Wilhelms Universitat, Bonn, Germany.157 p.

Stindt, A. and Weltzien, H.C. 1988. Der Einsatz von kompostextrakten zur bekampfun von Botrytis cinerea an erdbeeren ergebnisse des versuchsjahres 1987. Gesunde Pflanzen. 40: 451-454.

Thom, M and Moller, S. 1988. Untersuchungen zur wirksamkeit wasseriger kompostextrakte gegnuber edem erreger des echten mehltaus an gurken. Thesis. Gesamthochschule Kassel.

Urban, J. and Trankner, A. 1993. Control of grey mould (Botrytis cinerea) with fermented compost/water extracts. In: Fokkema, N.J., J. Kohl and Y. Elad (Eds.), Biological control of foliar and post-harvest diseases. Proceedings of a Workshop. West Palearctic Regional Section .16: 8-11.
Weltzien, H. 1991. Biocontrol of foliar fungal diseases with compost extracts. In: J.H. Andrews and S. Hirano (eds.) Microbial ecology of leaves. New York, NY, pp. 430-450.

Weltzien, H. and Ketterer, N. 1986. Control of downy mildew, Plasmopara viticola (de Bary) Berlese et de Toni, on grapevine leaves through water extracts from composted organic wastes. Journal of Phytopathology. 116: 186-188.

Weltzien, H.C. and Ketterer, N. 1986a. Control of downy mildew, Plasmopara viticola (de Bary) Berlese et de Toni, on grapevine leaves through water extracts of composted organic wastes. Jouranl of Phytopathology . 116: 186-188.

Weltzien, H.C. and Ketterer, N. 1986b. Control of Phytophthora infestans on tomato leavesand potato tubers through water extracts of composted organic wastes. Phytopathol; 76: 1104.

Yami, K. D. and Shrestha, A. 2005. Selective utilization of organic substrates during vermicomposting and the study of microflora. Journal of Nepal Biotechnology Association. 2: 23-26. 